\title{
Women and trade unions: an attitudinal survey
}

\author{
Gerard Griffin* and John Benson $\dagger$
}

This paper reports some of the findings of a questionnaire survey of 379 female members of the Australian Insurance Employees' Union (AIEU). The specific areas covered are general attitudes to trade unions and to joining and participating in the AIEU, womens' priorities for the AIEU and the perceived role of their union in work-related problems and womens' issues.

\section{Introduction}

A major development in Australian Trade Unionism during the 1970s was a substantial growth in the number of female union members. In the 12 year period 1970-1982, the total number of female union members increased by 423900 (75 percent) from 564100 to 988000 . During the same period male union membership increased by 237800 (16 percent) from 1750600 to 2024400 . Consequently, the female component of total membership changed from 1 in every 4 members in 1970 , to 1 in every 3 in 1982 . The expanding female labour force was a contributing factor to this growth rate. More important, however, was the unionization of hitherto unorganised sectors of the labour force, particularly the white-collar sector where female employees are in the majority. This is reflected in the female union density rate, the degree of unionization, which rose from 36 percent in 1970 to 49 percent in 1982.

The dramatic change in female union membership over such a short period of time inevitably generated a substantial literature on women and unions. This literature includes personal accounts by female activists (Nord, 1980), surveys of union officials (Horsley et al., 1980), interviews with individual union members (Hargreaves, 1982), analyses of the struggle for equal pay (Riches, 1982) and general overviews of the relationship between women and trade unions (Ryan and Prendergast, 1982, Wilkinson, 1983).

Several of these authors have commented on the relatively low number of female union officials. For example, Horsley et al., (1980) concluded from their study of 17 trade unions that ".... (the) results indicated under-representation of women at each level, from shop stewards and office representatives to organisers, research officers and members of executive committees" (p.12). They noted particularly a lack of full-time, paid female officials; all of the secretaries and assistant secretaries, the pivotal, influential positions, of the 17 unions were males. This can be contrasted with the 39 percent female component of the combined unions memberships. A further indication of the relative lack of female representation in the upper echelon of the Australian ${ }^{1}$ labour movement is provided by the composition of

* Labour Studies Programme, University of Melbourne, Victoria, 3052.

$\dagger$ Schools of Business and Social Sciences, Gippsland Institute of Advanced Education, Victoria 3842.

1. It should be pointed out that under-representation of females in official ranks is not confined to Australia. Reports by Geare et al. (1979), Le Grand (1978) and Aldred.(1981) indicate similar situations in New Zealand, the United States of America and the United Kingdom respectively. 
delegates to biennial Congresses of the Australian Council of Trade Unions. In 1983, 10 percent, 85 out of a total of 845 delegates, were females (Martin, 1983, p.108).

This non-representativeness, on a sex ratio, of union officials raises several issues for trade unions such as the attitutes of female members to unions, their level of participation in, and commitment to, their union and the necessity to assess the industrial priorities of female members. With the exception, however, of Storer's (1976) study of migrant women workers, no attempt has been made to uncover systematically the attitudes of a group of Australian female union members. ${ }^{2}$ The present paper provides a range of data on these issues based on questionnaires completed by 379 female members of the Australian Insurance Employees Union (AIEU).

\section{The Australian Insurance Employees' Union}

Established in 1920, the AIEU, with some 23000 members is the larger of 2 unions operating in the insurance industry. The second union, the AMP Society Staff Association with 4000 members, is not a competitor to the AIEU as its membership is restricted to employees of Australia's largest insurance company, the AMP Society. The organisational structure of the AIEU is typical of many Australian unions: biennial federal council, federal executive, branches based on the 6 states and office representatives at the shop-floor level. Ultimate power in the union resides in the Federal Council to which delegates are elected directly by the members. Between the biennial meetings of council, control of the AIEU rests with the Federal Executive which consists of the Federal Officers (President, VicePresident, Treasurer, Secretary and Assistant Secretary) plus the 6 branch presidents and 1 additional delegate from each branch.

Membership of the AIEU increased dramatically in the mid-1970s. This was a direct result of a decision by the Australian Conciliation and Arbitration Commission which granted preference in various aspects of their employment to unionised clerical workers in the oil industry (Griffin, 1983, p.30). Fearing a flow-on of this decision to the insurance industry, and consequent infringements on managerial prerogative, employers approached the AIEU and in return for union agreement not to seek the insertion of a preference clause in its awards, offered to make union membership a condition of employment for all new employees hired after 1 August 1974. The union accepted the offer which proved to be the major force behind the increase in membership from 15233 in 1974 to 20258 in 1976
and 23193 in 1983 .

A majority of new insurance employees since 1974 have been females. This has changed the membership composition of the AIEU. In 1973, 41.3 percent of the membership were females; by 1983, female membership had increased to 59.5 percent. This change in the grassroots level has not been reflected at any of the official levels. In 1983, all 5 federal officers and 11 out of the 12 federal executive deleates were males. At the state level, 1 branch secretary, out of 6 , and 2 branch organisers, out of 8 were females. Only 16 (19 percent) of the 85 members of the 6 states' branch committees of management were 319 (64 percent) males 178 ( 36 the office representative level, though to a lesser extent: 319 ( 64 percent) males, 178 ( 36 percent) females. Concern at the under-representation of the actions decided on by council was to the 1979 and 1981 federal councils. One of members. In late 1982, the authors were to authorise a questionnaire survey of female involved in the survey.

2. For a detailed study of female participation in trade unions in New York see Nelson and Wertheimer
(1975). 


\section{Methodology}

Following discussion with union officials, full-time and honorary, a first draft of the questionnaire was completed in December 1982. This draft was sent to all branch and federal union officials and to a number of researchers. Comments on any aspects of the questionnaire such as wording, omission and organisation were invited. A second draft taking these comments into account was prepared in January 1983. This draft was sent to a number of officials and was also pilot-tested on 20 female office representatives in Melbourne. The representatives were asked to complete the questionnaire and subsequently attended 2 lunchtime meetings in the Victorian branch office to discuss the questionnaire. A third, and final, draft was produced in March 1983 and the questionnaire was mailed to the home addresses of 1000 female members in April 1983. A covering letter from the AIEU Federal Secretary explaining the purpose of the survey and guaranteeing anonymity, and a reply-paid envelope was included with each questionnaire. A follow-up letter was sent to all possible respondents some 2 weeks later. In addition, an article in the AIEU journal Premium outlined the survey and encouraged members who received questionnaires to complete and return the questionnaire.

The sample size of 1000 was influenced both by the cost of the survey and an expected low rate of return. At the time of the survey total AIEU female membership was 13809 . Accordingly, the sample size was 7.2 percent of the survey population. The sample was randomly drawn from AIEU's computerised membership list.

Some 379 usable questionnaires were returned. Excluding the 23 unanswered returns (mainly wrong address) the response rate was 38.8 percent. In view of the usually low response rate by union members to questionnaires and the small percentage of members who normally vote in union elections (Davis, 1981) this rate of return was considered satisfactory. ${ }^{3}$

\section{Survey Findings}

\section{Attitude to unions and the AIEU}

The female unionists were asked to respond to 6 statements about unions in general. They were than asked to respond to the same 6 statements as they related to the AIEU. The results are presented in Table 1 below. Overall, the women who responded held favour-

Table 1 Attitude to unions and the AIEU $(N=372)$

\begin{tabular}{|c|c|c|c|c|c|}
\hline & $\begin{array}{l}\text { Strongly } \\
\text { agree }\end{array}$ & Agree & Uncertain & Disagree & $\begin{array}{r}\text { Strongly } \\
\text { disagree }\end{array}$ \\
\hline $\begin{array}{l}\text { Employees get better wages and conditions } \\
\text { because of unions (AIEU). }\end{array}$ & $\begin{array}{r}16.3 \\
(9.6)\end{array}$ & $\begin{array}{c}52.9 \\
(47.6)\end{array}$ & $\begin{array}{c}24.1 \\
(35.3)\end{array}$ & $\begin{array}{l}5.3 \\
(6.1)\end{array}$ & $\begin{array}{l}1.3 \\
(1.3)\end{array}$ \\
\hline $\begin{array}{l}\text { Unions (AIEU) interfere with the efficient } \\
\text { running of business. }\end{array}$ & $\begin{array}{c}4.0 \\
(0.8)\end{array}$ & $\begin{array}{l}15.7 \\
(3.5)\end{array}$ & $\begin{array}{c}34.3 \\
(27.5)\end{array}$ & $\begin{array}{c}40.7 \\
(60.0)\end{array}$ & $\begin{array}{c}5.3 \\
(8.3)\end{array}$ \\
\hline $\begin{array}{l}\text { Unions (AIEU) have too much power over } \\
\text { employers }\end{array}$ & $\begin{array}{l}9.6 \\
(1.1)\end{array}$ & $\begin{array}{l}21.6 \\
(4.3)\end{array}$ & $\begin{array}{c}31.5 \\
(34.4)\end{array}$ & $\begin{array}{c}33.3 \\
(53.2)\end{array}$ & $\begin{array}{c}4.0 \\
(7.0)\end{array}$ \\
\hline $\begin{array}{l}\text { Without strong unions (AIEU) individual } \\
\text { workers are at the mercy of their employers. }\end{array}$ & $\begin{array}{l}11.8 \\
(8.9)\end{array}$ & $\begin{array}{l}38.8 \\
(31.5)\end{array}$ & $\begin{array}{l}23.8 \\
(31.5)\end{array}$ & $\begin{array}{c}23.0 \\
(25.3)\end{array}$ & $\begin{array}{c}2.7 \\
(3.0)\end{array}$ \\
\hline $\begin{array}{l}\text { Union (AIEU) officials are genuinely } \\
\text { concerned with representing their members } \\
\text { interests. }\end{array}$ & $\begin{array}{c}6.7 \\
(8.1)\end{array}$ & $\begin{array}{c}42.6 \\
(51.1)\end{array}$ & $\begin{array}{c}33.4 \\
(32.0)\end{array}$ & $\begin{array}{l}13.5 \\
(7.0)\end{array}$ & $\begin{array}{c}3.8 \\
(1.9)\end{array}$ \\
\hline $\begin{array}{l}\text { Australia (Insurance Industry) would be } \\
\text { much better off without unions (AIEU). }\end{array}$ & $\begin{array}{l}7.0 \\
(2.7)\end{array}$ & $\begin{array}{c}7.0 \\
(3.2)\end{array}$ & $\begin{array}{l}32.6 \\
(32.5)\end{array}$ & $\begin{array}{l}42.5 \\
(50.3)\end{array}$ & $\begin{array}{c}11.0 \\
(11.3)\end{array}$ \\
\hline
\end{tabular}

3. The final returns represent 2.8 percent of total AIEU female membership, Given the method of analysis employed this is a more than sufficient sample size. See Moser and Kalton (1971). 
able attitudes to unions in general and the AIEU in particular. An attitude index was developed by allocating a numerical score of 1 to 5 to each of the 5 classifications and then summating that score for the 6 items. The scores could thus range between 6 and 30 with the higher the score the more positive the attitude. ${ }^{4}$

The mean score for attitude to unions was 19.91 (standard deviation 4.59) whilst the mean score for attitude to the AIEU was 21.14 (standard deviation 3.83). The difference between these means proved to be highly significant $(t=3.69 ; \mathrm{p}<0.001)$. This the women had a significantly more positive attitude towards their own union than unions in general. [The only exception was that in response to the question "Employees get better wages and conditions because of unions (AIEU)" respondents felt this was more the case with unions in general than their own union in particular.] This is not unexpected as their opinions can be related to an organisation and individuals they are familiar with. Equally, their attitudes to unions in general will reflect to some degree some of the popularly held beliefs concerning trade unions. Overall the female unionists felt that unions (and the AIEU) did not interfere with the efficient running of business, did not have too much power over employers, that union officials are genuinely concerned with representing their members and that Australia would not be better off without unions.

Individual total scores on both scales ranged from 6 to 30. It was hypothesised that 9 factors could explain a considerable proportion of the variation in attitudes: political preference, time worked in the industry, age, location of workplace, level of education, gross income, martial status, number of children and the AIEU's perceived handling of important issues. ${ }^{5}$ The 9 predictor variables accounted for some 15.75 percent of total variance in responses to the general unions scale (see Table 2). Some 14.13 percent was attributable to 2 variables; political preference ( 8.76 percent) and the perception of the AIEU handling of important issues (5.37 percent). In both cases, these proved to be statistically signficant. Thus, women were more likely to have positive attitudes to unions in general if they were supporters of the Australian Labor Party (ALP) or had positive views on the way the AIEU handled key issues. The 9 predictor variables accounted for 11.40 percent of total variance in responses to the AIEU scale (see Table 3 ). In this case some 10.91 percent was attributed to 3 variables: AIEU handling of issues ( 6.06 percent), gross income ( 3.1 percent) and

Table 2 Predicted variance in attitude to unions

\begin{tabular}{lccc}
\hline \multicolumn{1}{c}{ Variables } & $\begin{array}{c}\text { Variance } \\
\text { explained } \\
\%\end{array}$ & $\begin{array}{c}\text { Total } \\
\text { variance } \\
\%\end{array}$ & $\begin{array}{c}\text { Simple } \\
\text { correlation }\end{array}$ \\
\hline Political preference & 8.76 & 8.76 & -0.30 \\
AIEU handling of issues & 5.37 & 14.13 & -0.22 \\
Gross income & 0.94 & 15.07 & 0.05 \\
Marital status & 0.55 & 15.61 & 0.09 \\
Level of education & 0.05 & 15.66 & 0.08 \\
Age & 0.05 & 15.70 & 0.00 \\
Location of work & 0.03 & 15.73 & 0.03 \\
Time worked in industry & 0.01 & 15.74 & \\
Number of children & 0.00 & 15.75 & \\
\hline
\end{tabular}

4. Factor analysis was carried out on each of the 6 items making up the 2 attitude scales. All items loadings for each item and the loadings on factor 1 factors. Factor 1 loadings exceeded factor 2 some 77.3 percent of explained variance. The 1 were all in excess of 0.48 . Factor 1 occounted for loaded on 2 factors. Once again factor 1 loadings exceeded fap the attitude to the AIEU scale also between 0.29 and 0.66 . Factor 1 accounted for some 74.5 factor 2 loadings for each item and ranged on one major factor suggests that the 6 items making up each of the explained variance. The loading although the relatively low commonalities making up each of the attitude scales are unidemensional realiability of each scale.

5. Regression analysis, with dummy coding for dichotomous variables, was performed for each attitude
scale. 
Table 3 Predicted variance in attitude to AIEU

\begin{tabular}{lccc}
\hline \multicolumn{1}{c}{ Variables } & $\begin{array}{c}\text { Variance } \\
\text { explained } \\
\%\end{array}$ & $\begin{array}{c}\text { Total } \\
\text { variance } \\
\%\end{array}$ & $\begin{array}{c}\text { Simple } \\
\text { correlation }\end{array}$ \\
\hline AIEU handling of issues & 6.00 & 6.00 & 0.25 \\
Gross income & 3.10 & 9.10 & 0.17 \\
Political preference & 1.82 & 10.91 & 0.10 \\
Age & 0.22 & 11.13 & 0.08 \\
Marital status & 0.22 & 11.35 & 0.06 \\
Number of children & 0.02 & 11.37 & 0.03 \\
Location of work & 0.01 & 11.39 & 0.02 \\
Time worked in industry & 0.00 & 11.40 & 0.07 \\
Level of education & 0.00 & & 0.00 \\
\hline
\end{tabular}

political preference (1.82 percent). Only the first 2 variables proved statistically significant. Women were thus likely to have positive attitudes towards the AIEU if they perceived the AIEU handling important issues well or if they received a high income.

\section{Joining and remaining in the union}

As pointed out earlier, since 1974 , all new insurance employees have had to join the union as a condition of employment. This condition does not have the support of the majority of women members: 41.7 percent of women who responded disagreed with compulsory membership of the AIEU, 36.7 percent supported such membership while 21.6 percent were "unsure". Signficant support for compulsory unionism came from women in the over-30 age group and women who would generally describe themselves as supporters of the ALP.

Only 12.7 percent of all women surveyed had the choice of joining the AIEU. In view of the low union density rate among females prior to 1974 , it is surprising that only 14.8 percent of those surveyed indicated that they would not have joined the union if it was not a condition of employment. The strongest supporters for joining the union, if given a choice, were the women in the over-30 age group and ALP supporters, although only the latter proved statistically significant beyond the 0.01 level. Only 14.7 percent of all women indicated they would actually resign from the AIEU if given the opportunity. Once again, the strongest support for remaining within the union came from the over -30 age group and ALP supporters. In both cases this proved to be statistically significant (p.<0.01).

In part, this attitude reflects the perceived advantages of belonging to the AIEU. Table 4 breaks down the perceived benefits of union membership by those who would have joined voluntarily and those who felt they were compelled to join the AIEU. As was to be expected, women members of the AIEU who would have joined the union voluntarily saw significantly more benefit in belonging to the union than those women who felt they were forced to join the union. ${ }^{6}$ When taken collectively some 47 percent of all women surveyed felt that union membership offered benefits to them in terms of their work life.

\section{Table 4 Benefits of union membership}

\begin{tabular}{lcc}
\hline & Compulsory Member $(\mathrm{N}=80) \%$ & Voluntary Member $(\mathrm{N}=91) \%$ \\
\hline Substantial & 2.5 & 20.9 \\
Some & 13.7 & 51.6 \\
Few & 53.8 & 26.4 \\
None & 30.0 & 1.1 \\
\hline
\end{tabular}

6. A chi-squared test of frequencies yielded a $\chi^{2}=60.13$ which is significant beyond the 0.01 level. 
Table 5 Involvement in union activities

\begin{tabular}{|c|c|c|c|}
\hline & $\begin{array}{l}\text { Yes } \\
\%\end{array}$ & $\begin{array}{l}\text { No } \\
\%\end{array}$ & 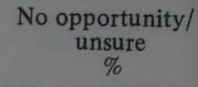 \\
\hline $\begin{array}{l}\text { Annual meeting }(\mathrm{N}=356) \\
\text { Branch union meeting }(\mathrm{N}=366) \\
\text { Company lunchtime meeting }(\mathrm{N}=368) \\
\text { Mass lunchtime meeting }(\mathrm{N}=366) \\
\text { Company stopwork meeting }(\mathrm{N}=365) \\
\text { Mass stopwork meeting }(\mathrm{N}=361)\end{array}$ & $\begin{array}{r}4.1 \\
6.8 \\
16.3 \\
15.6 \\
6.8 \\
5.5\end{array}$ & $\begin{array}{l}74.8 \\
69.9 \\
60.1 \\
62.6 \\
64.9 \\
55.8\end{array}$ & $\begin{array}{l}21.1 \\
23.2 \\
23.6 \\
21.9 \\
28.2 \\
27.7\end{array}$ \\
\hline
\end{tabular}

\section{Involvement in union activities and positions}

The female unionists surveyed had a minimal involvement in union activities. The extent and type of involvement is set out in Table 5. With the exception of lunchtime meetings, less than 10 percent of women members of the AIEU who responded to the survey took part in union activities. These figures are little different from data reported in other studies. When Davis (1981) studied the participation rate in union activities in 6 Australian unions he found attendance at annual meetings ranged between 0.12 percent and 5 percent; attendance at mass meetings was higher and ranged between 5 percent and 40 percent. In this context our survey results of 4.1 percent attendance at AIEU annual meetings and the 15.6 percent and 16.3 percent attendance at mass and company meetings respectively appear fairly standard. ${ }^{7}$

Some 26.8 percent of all women surveyed indicated they would attend an AIEU womens course and a further 43 percent were undecided. It would appear that women members of the union would like to become involved in union activities, the question remains as to what initiatives the union can develop.

Women in the AIEU have not played an active part in union government. Only 2.7 percent of women surveyed had stood for union positions, although in each case they were successful in obtaining office. Why women had not stood for postions within the union can be gauged from Table 6 . The major reasons included: "Too busy", particularly amongst the

Table 6 Major reason for not standing for AIEU position

\begin{tabular}{lrr}
\hline Intend staying in industry for short period & Number & $\%$ \\
Opposition to unionism & 32 & 8.9 \\
Lack confidence to carry out the job & 32 & 8.9 \\
Men better suited to union positions & 53 & 14.7 \\
Too busy with work/other interests & 5 & 1.4 \\
Don't know enough about the union & 110 & 30.6 \\
Family responsibilities & 64 & 17.8 \\
Ridicule/harrassment from workmates & 25 & 6.9 \\
Other reasons & 5 & 1.4 \\
\hline
\end{tabular}

over 21 year olds, "Don't know enough about the union" and "Don't feel confident to newer members. Only some 6.9 perent reasons were prevalent amongst the younger and would prevent them from becoming active in women surveyed felt family responsibilities

\section{Important industrial issues}

Respondents were asked to list the 5 issues that should be the main priorities of the

7. These figures may overstate the true attendance rates as they are aggregate figures - the questionnaire
asked whether the women had ever participated in the data reported by Davis are observed attendance rates. 
able 7 Important industrial issues

\begin{tabular}{|c|c|c|c|c|c|}
\hline & $\begin{array}{c}\text { Priority } 1 \\
(\mathrm{~N}=362) \\
\%\end{array}$ & $\begin{array}{c}\text { Priority } 2 \\
(\mathrm{~N}=361) \\
\%\end{array}$ & $\begin{array}{c}\text { Priority } 3 \\
(\mathrm{~N}=359) \\
\%\end{array}$ & $\begin{array}{c}\text { Priority } 4 \\
(\mathrm{~N}=354) \\
\%\end{array}$ & $\begin{array}{c}\text { Priority } 5 \\
(\mathrm{~N}=347) \\
\%\end{array}$ \\
\hline lealth and safety & 30.7 & 15.5 & 14.2 & 8.8 & 10.7 \\
\hline uperannuation & 2.5 & 7.2 & 6.4 & 9.3 & 11.0 \\
\hline echnological change & 2.8 & 5.5 & 7.2 & 7.9 & 10.4 \\
\hline Vages & 12.4 & 13.0 & 14.8 & 17.8 & 14.4 \\
\hline hildcare & 0.6 & 1.9 & 2.8 & 3.4 & 5.8 \\
\hline ob security & 33.7 & 19.4 & 17.8 & 9.3 & 6.9 \\
\hline horter hours & 1.1 & 3.0 & 1.9 & 1.7 & 1.7 \\
\hline art-time work & 0.6 & 3.9 & 4.7 & 6.8 & 7.2 \\
\hline Vork conditions & 3.0 & 12.2 & 11.4 & 16.4 & 14.1 \\
\hline qual opportunities & 11.9 & 17.7 & 17.8 & 16.1 & 16.7 \\
\hline iocial issues & 0.8 & 0.6 & 0.8 & 2.5 & 1.2 \\
\hline
\end{tabular}

AIEU. Their responses are detailed in Table 7. Four issues dominated the womens' first priority: job security (33.7 percent), health and safety ( 30.7 percent), wages ( 12.4 percent), and equal opportunity (11.9 percent). The high ratings of the job security and health and safety issues warrant coment. The women's rating of job security is related to the shrinking workforce in the insurance industry. Between 1975 and 1982, employment in the life and general segments of the industry, the segments from which the AIEU draws the bulk of its members, decreased by approximately 5000 . Initially, this reduced workforce was achieved through natural wastage with few redundancies. The late 1970 s and early 1980 s however, have seen a substantial growth in the number of redundancies in the industry. This development, allied with AIEU publicity and campaigns, accounts for the job security ranking. The high priority given to the health and safety issue may also be partially attributable to union actions and campaigns. Over the past 3 years many AIEU publications have discussed the possible health hazards of white collar work such as eye strain due to visual display units and repetitive strain injuries such as tenosynovitis linked to continuously inputing data to computers.

In addition to first priorities, each of the 4 main issues were nominated as amongst the 5 most important priorities for the AIEU by a substantial majority of the women surveyed: job security (87.3 percent), health and safety (79.9 percent), wages ( 72.4 percent) and equal opportunity ( 80.2 percent). The support for these issues was not however universal. Job security was more important to the high income earners, wages to the lower income earners and equal opportunities to those respondents under 21 years of age. Issues that could be perceived to be important to female union members such as part-time work, childcare facilities, shorter hours and technological change were not considered issues of high priority. This does not mean that such issues are viewed as unimportant of themselves but rather that the female members felt that the AIEU should, as a priority, concentrate on other issues.

Respondents were then asked to describe the AIEU's handling of their first priority on a 7 point scale ranging from completely satisfactory to completely unsatisfactory. 53.2 percent were satisfied with the AIEU's handling of the issue, 34.0 percent unsure or did not know, and only 12.8 percent expressed some level of dissatisfaction. To discover whether levels of satisfaction and dissatisfaction varied with various sub-groups of the sample, regression analysis was carried out. The classifications were, political preference, gross income, age, level of education, time worked in the insurance industry and the length of membership with the AIEU. In all cases, variations within these classifications failed to explain a significant or substantial amount of variance in respondents perception of the AIEU's handling of industrial issues. ${ }^{8}$

8. The 6 variables, taken collectively, only explained some 4.8 percent of total variance. 
Table 8 Why respondent would not seek AIEU help

\begin{tabular}{lrr}
\hline & Number & $\%$ \\
\hline Solve myself & 70 & 57.9 \\
Union unable to help & 8 & 6.6 \\
Lack confidence to go to union & 9 & 7.4 \\
Don't want trouble with management & 24 & 19.8 \\
Other & 10 & 3.2 \\
\hline
\end{tabular}

\section{Work Problems}

Women, when faced with a problem at work, are reluctant to approach the AIEU. Only 36.5 percent of all women surveyed would approach the union and these tended to be the older employees and the ones that generally supported the ALP. In this survey 2 significant factors stood out. First, women would be more likely to approach the AIEU if the union had an office representative in their company and, second, they would be more likely to approach the union if they know who the relevant full-time union official was. ${ }^{9}$ This latter factor was related to whether the union official had visited the company, although the relationship did not prove significant.

Table 8 summarises the reasons given by women for not seeking the assistance of the AIEU. By far the most common reason was that they preferred to solve the problem with management themselves. This could also be related to the view that in solving the problem women did not want trouble with management by involving the union. In general, those women who preferred to solve problems themselves were more likely to be on higher incomes, had spent longer working in the industry, had reached higher levels of education and tended to support the more conservative political parties. The other major group were those women who did not want trouble with management by involving the union. This group included those women relatively new to the industry, those on lower incomes and those who had recently joined the AIEU. In both cases, these factors did not prove to be statistically significant.

\section{The union and women's issues}

The women surveyed were asked to assess the ability of the AIEU leadership to represent the interests of women members. The results are presented in Table 9 . Some 42 percent were satisfied with the present leadership of the union. This compares with only 8.3 percent who expressed dissatisfaction. This latter group was predominantly the younger and consequently newer union members. However, nearly half (49.6 percent) of the women either did not have any opinion on the leaderships' ability to represent their interests or did not know enough about the leadership to venture an opinion.

Two possible initiatives discussed within the union which could make the AIEU more responsive to womens' issues are the appointment of a women's officer and the establish-

Table 9 AIEU leadership representation of women members

\begin{tabular}{lrr} 
& Number & $\%$ \\
Very Good & 24 & 6.4 \\
Good & 65 & 17.4 \\
Adequate & 68 & 18.2 \\
Unsure / Don't know & 185 & 49.6 \\
Inadequate & 22 & 5.9 \\
Poor & 5 & 1.3 \\
Very poor & 4 & 1.1 \\
\hline
\end{tabular}

9. Specific company offices are allocated to specific AIEU officials. 
Table 10 AIEU initiatives to improve representation of women

\begin{tabular}{lcc}
\hline & $\begin{array}{c}\text { Women's Officer } \\
(\mathrm{N}=376) \\
\%\end{array}$ & $\begin{array}{c}\text { Women's committee } \\
(\mathrm{N}=376) \\
\%\end{array}$ \\
\hline Very good idea & 22.9 & 13.0 \\
Good idea & 43.9 & 27.7 \\
Unsure & 24.7 & 38.0 \\
Bad idea & 7.1 & 19.9 \\
Very bad idea & 1.1 & 13.0 \\
\hline
\end{tabular}

ment of a womens' committee. Reactions of the women surveyed to both these initiatives are presented in Table 10. Some 66.8 percent agreed with the appointment of a women's officer and 40.7 percent supported the establishment of a women's committee. On this latter initiative, 12 percent of all women surveyed would be prepared to participate if such a committee was formed. A cross tabulation of these opinions with personal characteristics indicates that the younger and more recently joined women members did not have definite opinions on these two initiatives, many falling into the "Don't know" category.

\section{Conclusion}

The women who participated in the survey held favourable attitudes on trade unions in general and the AIEU in particular. A substantial majority had to join the union as a condition of employment but only 15 percent indicated that, if given the choice, they would not have joined the union. For most, paying membership fees is the extent of their participation: the women had a minimal involvement in union activities such as attending meetings. Issues of priority for the union were job security, health and safety, wages and equal opportunities. Just over one-third of the women surveyed would approach the AIEU for assistance with work related problems. Finally, women strongly support the appointment of a women's officer within the AIEU, but indicated less support for a women's committee.

\section{References}

Aldred C (1981) Women at work London, Pan.

Davis E (1981) Participation in six Australian trade unions Journal of industrial relations 23 (2) : 190-215.

Geare A, Herd J and Howells J (1979) Women in trade unions: a case study of participation in New Zealand Wellington, Victoria University of Wellington (Industrial Relations Monograph No. 6).

Griffin G (1983) White-collar unionism 1969 to 1981: some determinants of growth Journal of industrial relations 25 (1) : 26-37.

Hargreaves K (1982) Women at work Melbourne, Penguin.

Horsley P, Martin C, Winzar P, Mattarozzi M and Weate J (1980) Women and unions: a pilot study Melbourne, Community Research Action Centre, Monash University Union.

Le Grand L (1978) Women in labor organizations: their ranks are increasing Monthly labor review $101(8): 8-14$.

Martin R (1983) The ACTU Congress of 1983 Labour history 45 : 101-112.

Moser C and Kalton G (1971) Methods in social investigation London, Heinemann. 


\section{Griffin and Benson}

Nelson A and Wertheimer B (1975) Trade union women: a study of the participation in New York city locals, Ithaca, Cornell University.

Nord S (1980) Right-wing union officials versus married women workers. In Windschuttle E (Ed.) Women, class and history: feminist perspectives on Australia 1788-1978 Melbourne,
Fontana.

Riches L (1982) The struggle for equal pay in the Australian private banking industry 1966-1975. In Bevege M et al. (Eds) Worth her salt: women at work in Australia Sydney,
Hale and Ironmonger.

Ryan E and Prendergast H (1982) Unions are for women too. In Cole K (Ed.) Power conflict and control in Australian trade unions Melbourne, Pelican.

Storer D (1976) But I wouldn't want my wife to work here ... a study of migrant women in Melbourne industry Melbourne, Centre for Urban Research and Action.

Wilkinson J (1983) Unions and women workers. In Ford B and Plowman D (Eds) Australian unions: an industrial relations perspective Melbourne, MacMillan. 